\title{
A CRISE DA NAÇÃO NA SAGA DE ALMEIDA FARIA
}

Lilian Jacoto

Universidade de São Paulo

Não perdi a minha alma,

Fiquei com ela perdida

Mário de Sá-Carneiro

C

omo conceito filosófico e político, a idéia de nação é um legado do século

dezenove: sobre ela se apoiou a reação dos Estados europeus à hegemonia napoleônica, e também o mito romântico de que a revolução libertária se deveria firmar sobre valores identitários resgatados à pré-história de cada povo. Esse resgate fomentou o estudo das línguas nacionais e da poesia arcaica como códigos reveladores da essência coletiva. As idéias de Rousseau para quem nação e revolu $\div$ ão se confundiam - e de Herder - na língua e sobretudo na poesia estariam registradas as experiências arquetípicas de um povo - contagiaram o século romântico de um nacionalismo eufórico que acabou por legar, ao século XX, algumas de suas mais graves contradições.

O fato é que, após as experiências amargas dos totalitarismos e guerras mundiais, hoje reconhecemos que a idéia romântica de nação - como identidade espontânea que aflora no exercício diário de uma cultura - se por um lado delimitou fronteiras geográficas, lingüísticas, raciais e míticas, por outro acobertou o uso político que o Estado dela veio fazendo, como instrumento de adesão ideológica, através de rituais e símbolos tão aliciantes quanto os utilizados, desde sempre, pela Igreja.

Hoje, mediante relações de interdependência econômica que extravasam, em muito, as fronteiras geopolíticas dos países, assistimos ao lento desmoronamento das nações, marcadamente observável nos países que viveram a ascensão e colapso de ditaduras, cujas ideologias se apegaram a alguns valores identitários eleitos, ao sabor da hora, para firmar um pacto 
de fidelidade entre o cidadão e o Estado. Com a formação de blocos econômicos continentais, fica-nos visível o quão arbitrários eram os critérios que delimitavam as nações: lingüísticos, genéticos, geográficos, religiosos - cada Estado buscou suas formas subliminares de adesão e expansão da identidade nacional, sempre com a finalidade de criar e manter o sentimento de que haveria laços naturais profundos entre os cidadãos, coincidentes e reveladores de uma nacionalidade mais construída e ditada do que realmente sentida.

O desmantelamento da idéia de nação tem gerado seqüelas trágicas nos países onde o Estado totalitário demorou a cair. Portugal está entre eles, aos poucos despindo o luto de uma ditadura que pareceu eterna, vitalícia. Nele, a lenta erosão do salazarismo deu lugar a uma crise de identidade nacional que se contamina de toda a amargura existencialista advinda dos meados do século XX.

A Revolução dos Cravos, ao fim e ao cabo, parecia querer resgatar aos lusitanos aquele momento agudo de reflexão que a França vivera havia quase duzentos anos: afinal, o que o povo português concebia como nação? Quais os critérios para se autodelimitar - étnico, geográfico, lingüístico? $\mathrm{Na}$ revolução tardia, a crise se complicava no novo cenário europeu e mundial: como manter os vínculos culturais e econômicos na África incendiada pelas guerrilhas de libertação? Como se posicionar no contexto da Guerra Fria, vendo-se à margem da Europa e de sua passada grandeza como potência do além-mar?

Nesse auto-exame de Narciso frente ao espelho estilhaçado, nunca o romance foi tão oportuno. Exercitando-se na sua abrangência e inventividade, tem recontado a História inúmeras vezes, como se a nação quisesse mesmo desaver-se consigo mesma, carnavalizando-se, desconstruindo seus mitos e virando-os do avesso. De repente D. Sebastião reaparece num ovo boiando no mar, após um cataclisma. Ressurge como bon vivant e ladino, desinteressado da política externa e agnóstico. Retornado sem passado nem linhagem, não lhe apetece agora a conquista de impérios, mas tão somente dos corações femininos.

Essa é uma entre as tantas reinvenções que o romance contemporâneo pôde, a bom termo, realizar. Trata-se, como já é notório, da trama de $O$ conquistador, escrito por Almeida Faria, do qual extraímos um trecho ilustrativo das nuances que acima resumimos, narrado na voz do próprio Sebastião redivivo: 
Numa tarde de feliz e falso resfriado, na época pubertária em que não pensava sequer em Kama-Sutras e camas-supras e naquilo que até os dinossauros faziam, como Deus mandava e como só Deus sabia, li que Ulisses, há oito anos de serviço cívico ao leito de Calipso, ansiava por deixar a ilha de Ogígia e regressar à condenada condição mortal que o aguardava em Ítaca. Fiquei furioso: achei o cúmulo que alguém preferisse a decadência física às intermináveis delícias da ninfa e da ilha. Que bestice! Seria crível que um herói, conceituado após uma década de passatempos bélicos, se fartasse dos menos trabalhosos feitos eróticos? Nunca gramei guerreiros. Desde então detestei-os. (FARIA, 1990, p.65)

Mas não se pense que essa inversão burlesca tenha aparecido na obra de Faria assim de chofre, sem o trabalho da lenta desconstrução do mito que, para os portugueses, é civilizatório. O conquistador é, certamente, produto de uma ficção liberta do compromisso histórico, amiúde cumprido ao longo da tetralogia que o precedeu. Bem mais aderente aos fatos na sua crueza, a saga do Alentejo, ou Tetralogia lusitana, constrói, através da crise do clã de Montemínimo, uma alegoria do país em revolução. Ali o momento histórico de 1974 compromete seus heróis numa busca libertadora, seja ela coletiva ou pessoal, ao mesmo tempo que lhes delega a responsabilidade de reformular a idéia de nação, no momento agônico da Guerra Fria.

Para isso, Almeida Faria inicia sua saga com um romance lírico, $A$ paixão (1965), cujo título aponta para a sexta-feira cristã, como um pano de fundo mítico a fundamentar a história da família alentejana. Diferente dos demais romances da tetralogia, $A$ paixão, escrito ainda na vigência da ditadura, sobrepõe o tempo mítico ao histórico: o despertar matinal das personagens, o fogo que se alastra à tarde pela plantação e a última ceia da família unida são três momentos enfocados que confundem fatos e ritos, mergulhando todos os elementos narrativos numa dimensão simbólica. $A$ paixão, ao narrar o dia fatídico do clã de Montemínimo, alegoriza o momento de crise de todo um país, ao mesmo tempo que expõe os laços imemoriais dessa família fundamentados no cristismo. Por vezes a linguagem bíblica é resgatada, e o ritual do sacrifício parece detalhadamente reproduzido do Velho Testamento, ainda que ele aconteça apenas na mente da personagem João Carlos, a quem podemos referir tão-somente pelas sugestivas iniciais: 
São mais que horas, pensou ele, acordando; está já muito calor e hoje é o dia; na vila haverá vozes, altas e lamentosas, dos animais que morreram; imolarei também; ele é, o nosso cordeiro, como as palavras mandam; sem mancha, macho, dum ano; agora vou matá-lo, dentro da madrugada; num golpe brusco, grave, lhe abrirei a garganta, com a faca que gargantas abriu já antes desta, que a sóis outros brilhou iguais aos de hoje, que outrora se cobriu do mesmo sangue. (FARIA, 1966, p.14)

Aqui os tempos verbais se misturam: o passado imemorial, o presente da enunciação, e o futuro instaurador do caráter profético da narração. A coexistência desses tempos, na anunciação do ritual de sacrifício do cordeiro, confere polissemia ao despertar de João Carlos: ele é o que desperta para uma realidade, a um tempo, cotidiana (o dia que amanhece), mítica (a madrugada em que se realizará a imolação do cordeiro imaculado) e histórica (o momento da ação política que sacrificará sua inocência).

Perceba-se, ainda no trecho citado, a incoerência dos tempos que se sobrepõem uns aos outros, violando a linearidade cronológica e dramática: o tempo objetivo é o da manhã já despontada (“são mais que horas”); o tempo mítico registra a ação ritualística num futuro verbal que, na contramão do primeiro, passar-se-á na já pretérita madrugada (“agora vou matá-lo, dentro da madrugada”). Esse futuro ilógico do ritual instaura-se como aspecto verbal da ação enquanto virtualidade, uma vez que o monólogo interior da personagem pratica o sacrifício não em ato, mas na imaginação. JC desperta e mentaliza a cena da imolação. Seu discurso é pura transformação do ritual em mito.

É assim que o romance elege um mito fundador, um pacto estabelecido entre o humano e o divino, o qual implica imolação e transcendência. Entre a força mítica e a fragilidade humana - dualidade comum no espaço aldeão , João Carlos cumprirá o papel de filho pródigo ou cordeiro imolado para que o clã se renove. Rompendo os laços e abandonando a casa paterna, ele representa toda uma geração sacrificada à angústia do interregno pós-revolucionário, fadada a assistir à derrocada de todos os valores tradicionais que ela mesmo renegara. A tetralogia expõe essa dupla face do processo revolucionário, ao mesmo tempo glória e sacrifício, na medida em que o rompimento brusco com toda o passado abala profundamente a identidade da nação, e suspende, na angústia da liberdade, um sentido positivo de futuro. Ademais, 
mediante o contexto da Guerra Fria e das pressões internacionais, num jogo em que Portugal entrava tarde e enfraquecido, essa mesma geração teve a inglória missão de atuar na deliqüescência das utopias que, ao longo do século, tragicamente ruíram:

Durante as minhas insônias crepitantes penso que não me pertenço, sou não eu mas um povo inteiro perdido de si, confusamente à procura de não sabe que saída. Já em Lisboa pensava isso olhando as ruas degradadas a que os murais revolucionários ainda davam tons de revolta ou de ironia contra a história que nos tem andado a enganar. (FARIA, 1987, p.183)

D’A paixão ao Cavaleiro andante, a tetralogia realiza uma sucessão de cortes traumáticos com todos os traços identitários da nação que a ditadura salazarista pregava. A dispersão familiar causada pela fuga de JC é seguida por fatos sucessivos de violenta ruptura e transformação do cenário doméstico: o pai Francisco, senhor arruinado e malquisto pela esposa, filhos e trabalhadores, é cruamente assassinado pelos empregados, num gesto de repúdio violento à opressão patriarcal acumulada pelos séculos da fides vassálica. À morte dele segue-se o suicídio por enforcamento de Moisés, empregado velhíssimo da herdade, cujo nome resgata a credulidade humilde do patriarca bíblico. Com Moisés morre o elo moral e religioso até então mantido com o passado medievo, pilar pré-histórico da nacionalidade. Duas figuras, portanto, emblemáticas da velha ordem, cujas mortes violentas têm o duplo sentido de libertação e orfandade.

No que tange ao trauma da dupla orfandade que, alegoricamente, retrata a nação destituída concomitantemente da figura do líder e da divindade protetora, a tetralogia utiliza duas personagens infantes para dar voz aos anseios de compensação mítica da arraia miúda. Em seus devaneios escapistas, os filhos mais novos Jó e Tiago recorrem a espaços lendários que retomam figuras de autoridade resgatadas à pré-história de sua cultura. Sobretudo na imaginação de Jó - cujo nome resume a condição de "filho em provação pelo abandono de Deus" - aparece o Rei Artur e sua poderosa corte de heróis cavaleiros, no estágio de cristianização da lenda que associa a esse rei os valores medievais que formaram o substrato cultural da nação. A generosidade paternal do líder, aliada ao poder guerreiro e espiritual arturianos dão a 
medida da lacuna deixada pelas autoridades políticas recentes, conspurcadas pelo regime autoritário ainda muito fresco na memória popular.

Nos filhos adultos, entretanto, a orfandade transforma-se em compromisso libertário assumido nos planos individual e coletivo. André, JC e Arminda, com seus respectivos pares amorosos, são como jovens cavaleiros em idade de provação. Universitários, críticos e, em maior ou menor grau, politizados, esses jovens vivem a angústia de encontrar um lugar ao sol num país à deriva. Alegoricamente o primogênito viverá a agonia do velho sonho expansionista: adoece e, em vão, tenta a cura física e financeira num Brasil sem fortuna fácil, e que não reconhece mais, entre si e o lusitano, nenhum grau de parentesco. Mas, antes disso, a doença de André teve origem na guerra insana vivida a contragosto em África, e que o levara à deserção e ao retorno humilhado. Por fim, André morrerá tragicamente em Angola, onde poderia transformar-se num migrante-cidadão, disposto a reparar os danos coloniais que o Estado português, já à revelia da nação, teimava em manter. Dessa forma, também numa dimensão alegórica, André representa a quebra do pacto ideológico entre cidadão e Estado, maldizendo a guerra que dizimava jovens despreparados e absolutamente contrários à manutenção de uma política externa anacrônica e insana. André é fruto de um século cujas guerras só fizeram deslegitimar todo e qualquer nacionalismo, na medida em que o aparato bélico que as sofisticava só expôs a barbárie, de repente revelada, subsistente e intacta, nos Estados modernos.

A morte trágica de André, em última instância, é também a consumação da falência de um conceito de nação que, em Portugal, nasceu na Idade Média como sonho guerreiro e expansionista, cumpriu-se na Idade Moderna como império e, a despeito dos revezes históricos, assim se manteve como auto-imagem enganosa e anacrônica até a abalo moral do ultimato inglês, que lançara o país na realidade adversa do século XX. Sacrificando tão cara personagem de sua tetralogia, Almeida Faria parece declarar, em alto e bom som, a morte do auto-engano coletivo. Por outro lado, entretanto, ao deixar um possível filho no ventre da angolana Sônia, o herói teria sugerido um outro conceito, nascente, de nação: distante do pacto estabelecido com o Estado colonialista em deposição, agora o herói se escolhe como cidadão de um novo país que muita influência recebera de sua cultura, e que, noutro território, noutro clima, noutra conformação sócio-política, poderia, enfim, ajuda-lo a construir uma nova identidade. 
Por outro lado, na estrutura epistolar assumida a partir do terceiro romance, Lusitânia, o auto-engano torna-se importante objeto de análise e discussão, uma vez que, nas missivas trocadas entre familiares e amantes, os mitos pessoais se projetam e se desmascaram, pelo feed-backs que os interlocutores arriscam trocar via correio. João Carlos e Marta, por exemplo, formam uma dupla que debate, por escrito, questões de estética que a ambos interessam, uma vez que ele é poeta, e ela uma estudante de Belas Artes que permanece retirada em Veneza durante o período revolucionário. Para além do jogo amoroso de sedução e resistência que as cartas sustêm, seus debates tematizam, por exemplo, o grau de distanciamento que a arte deve ou pode ter do processo histórico, bem como o posicionamento de cada um sobre os dois eixos artísticos que confluem na mundividência portuguesa: de um lado o eixo gótico-barroco-romântico, representado por JC, versus o classicismo que Marta não se cansa de admirar no cenário renascentista. É, aliás com base nessa visão de mundo calcada na harmonia e na justa medida que a veneziana faz a JC sua crítica mais contundente, de tal maneira que retrata e desmascara, no lirismo incontido do poeta, o cristocentrismo atávico que emperra o destino não só dele, mas de toda a nação:

Vou confessar uma das coisas que aprendi: não gosto das tuas cartas, banais, sempre iguais, lamuriantes, duma tristeza deprimente. (...) Nada mais artificial que a situação em que vives. "Artificial”, que é isso? Artificial é o sacrifício, essa idéia repugnante, cristã até o nojo, esse falso valor em cujo nome se mataram milhões. Os hoje chorantes, os amanhã cantantes, que obscena mentira. (FARIA, 1987, p.209-210)

Essa obsessão do martírio é, ao fim, o obstáculo que separa não só o par amoroso, mas também a nação do tempo presente, dotando a imagem inicial de sacrifício do cordeiro, em $A$ paixão, de uma dimensão emblemática que muito tem a dizer sobre o comportamento coletivo, tão resistente à assimilação dos novos tempos, em que o exercício político demanda ações positivas de enfrentamento das mazelas sociais e econômicas e o abandono de quaisquer expectativas projetadas no plano transcendente. Essa encruzilhada histórica é bem ilustrada pela descrição que JC nos dá do cenário lisbonense no período pós-revolucionário: 
Em plena era revolucionária surgem crenças e fés de desespero, em Lisboa a estátua a Sousa Martins, espécie de Cristo Médico, orador, filantropo, patriota do século passado, aparece carregada de flores, velas, retratos, pernas e braços e peitos de cera em pedidos e pagamentos de promessas, mulheres passam horas ajoelhadas diante do monumento no Campo de Santana, indiferentes ao trânsito, à propaganda gritada pelos altifalantes ambulantes mobilizando militares para comícios e greves. Será que vão realizar-se as profecias do Bandarra, que prometeu um Quinto Império a quem perdeu o seu? Será que um rei amado porque louco, incompetente e morto, em breve retornará, não para de novo nos lançar em perdidas batalhas, mas para nos salvar de todas as desgraças e ameaças de maiores males? Será que o Alumiado trará consigo o abre-te-sésamo da fortuna e progresso ou por nossos pecados é preciso partir à procura da chave que abrirá a cave onde se esconde e não se encontra o Graal? (FARIA, 1987, p.19-20)

A Tetralogia lusitana, através da exposição desses conflitos entre tendências atávicas e necessidades históricas, convida a uma reflexão profunda sobre o processo de reconfiguração da nação portuguesa após a crise que os traços identitários sofreram desde o fim do salazarismo. Curioso, entretanto, é que também permite, em meio à desconstrução de seus mais caros mitos, entrever o ressurgimento do conceito romântico de nação, ou seja, a identidade que aflora espontaneamente no indivíduo, à revelia do pacto subliminarmente firmado nos anos de chumbo:

Fado e touradas, símbolos do nosso antigo regime, são agora mal vistos, o primeiro porque a noção de destino não existe em eras progressistas, as segundas por representarem uma luta improdutiva entre homens e bichos, ainda por cima com o defeito de defenderem códigos machistas sob o pretexto de viris. Nunca senti simpatia por tais rituais, só começam a interessar-me por oposição aos dogmas dominantes: a melancolia da nossa música "nacional" misturada às artes do toureiro a cavalo e à vaidade de pegar touros de graça, sem prêmio senão a auto-afirmação, o prestígio junto de certas mulheres, além de dentes partidos ou costelas, tudo isso me parece menos grave que outrora (...). À moral oportunamente opressiva anteponho a minha moral gratuita cuja finalidade está em si, mas não deixa de ser moral assim. (FARIA, 1987, p.30) 
Neste trecho de carta enviada por JC a Marta evidencia-se, por fim, que a revolução portuguesa, ao contrário daquelas que sucederam no século romântico, exerceu o papel de desvincular os valores nacionais dos pactos assumidos, ainda que subliminarmente, entre o povo e a classe dominante ou as esferas do poder. As trajetórias de André e JC, os cavaleiros andantes de Almeida Faria, parece que auxiliam o trabalho que a ficção pós-revolucionária delegou a si mesma: desconstruir os valores ditos nacionais sem, contanto, constranger a afirmação espontânea de uma nacionalidade renovada, que deixa ao indivíduo a livre escolha de seus valores, seu espaço e seus modelos míticos de conduta, agora menos inconscientes.

\section{BIBLIOGRAFIA}

FARIA, Almeida. A paixão. 2ª ed. Lisboa: Portugália, 1966.

FARIA, Almeida. Cavaleiro andante. $3^{\text {a }}$ ed. Lisboa: Caminho, 1987.

FARIA, Almeida. O Conquistador. Lisboa: Caminho, 1990. 